\title{
Comentarios al Código de Procedimientos Penales
}

\section{El Ministerio Público}

\author{
por el Dr. DOMINGO GARCIA RADA
}

En su origen histórico, la institución del Ministerio Público aparece con posterioridad a la judicatura. Los tratadistas están acordes en que es una de las magistraturas más antiguas, pero que sus caracteres actuales sólo se presentan en época reciente. Se explica este fenómeno porque las instituciones nacen como resultado de las necesidades de los pueblos y para que se impongan al legis'ador, es necesario el transcurso del tiempo.

En la sociedad primitiva, la venganza estaba a cargo del agraviado como único medio de castigar el hecho delictuoso, lo cual producia resultados contradictorios. A veces los físicamente fuertes se excedian en la sanción individual; en otros casos se originaba la impunidad, al carecer la victima de la fuerza fisica necesaria para tomar por si misma represa'ias o del dinero requerido para que otros lo hicieran en su nombre. Con frecuencia la venganza de los agraviados era desproporcionada con el hecho cometido. La Ley del Túlión al establecer que el castigo debia estar en relación con el delito constituyó notable avance.

Cuando el Estado quiso poner freno a esta situación, asumió el monopolio de la penalidad. Sólo él podia castigar a quienes infringieran agravios. Surgió entones la necesidad de funcionarios públicos que se dedicarán a la investigación de los delitos para deslindar responsabilidades y aplicar sanciones. Esta actividad del Estado no estaba circunscrita a instıtución o persona determinada.

En Grecia existian funcionarios encargados de denunciar los atentados contra la democracia y las prevaricaciones de los funcionarios. Plutarco elogia a Lúculo porque éste había formulado denuncia contra un poderoso. En

- Vocal de la Corte Suprema de Justicia. Ex-Decano de la Faculiad de Derecho de la Universidad Católica. Catedrâtico titular de Derecho Procesal Civil. 
Roma, encontramos funcionarios encargados de perseguir a los delincuentes, y los propios abogados ejercían en parte esta función, pues podian denunciar malversaciones de fondos, captándose asi la simpatia popular. Pero como eran premiados con los bienes de los despojados, pronto se llegó al abuso, constituyendo los delatores una verdadera p'aga para el pueblo romano. La institución de la Censura estaba destinada a vigilar la conducta pública de los ciudadanos en general y de los magistrados en particuiar. En el siglo IV, el Emperador Justiniano encomendó funciones judiciales a los Obispos.

En la Edad Media, los Missi Dominici de Car'omagno que recorrian las provincias e informaban al Emperador, exan verdaderos fiscalizadores de la administración pública.

La opinión rsás generalizada es que el Ministerio Fiscal, tal como hoy lo entendemos, tiene su origen en los funcionarios que crearon los señores feudales franceses, cuya misión primitivamente fue la percepción de las regalias, pero que at acrecentarse el poder real, adquirieron las facultades de los intereses del Rey primero, y de la sociedad después.

Es a comienzos del siglo XIV - año de 1302 - en que mediante una Crdenanza, se insituye en Francia un representante especial que conjuntamente con los intereses del Estado, defiende los de la sociedad y al que se le asigna, por primera vez, la ob'igación de intervenir en las causas de ca rácter penal, con el evidente propósito de suprimir la denuncia particular y evitar el "chantage" que habia llegado a erigirse en sistema. Rápidamente se extiende y afianza la institución y una Crdenanza de 1679 señaló sus caracteres de modo definitivo. La Revolución Francesa que suprinió todo cuan. to había sicio creación de la Monarqua, respetó, sin embargo, a los Procuradores, consclidando la institución e independizándola. Por ley de 20 de Abril de 1810 pasó a ser dependencia del ejecutivo. Estos antecedentes determinan que se sostenga que el origen de esta magistratura debe buscarse en Francia.

E1 primer representante personal de la Corona de España que toma el nombre de Procurador General o del Rey, aparece en 1387. Las Partidas hablan del Patronus Fisci encargado de ćefender "las cosas y derechos que pertenecen a la Cámara del Rey". En sus comienzos estos Procuradores -tanto en Francia cono en España- eran déiegados del Rey y su misión principal consistía en cuidar el patrimonio real y de sus prerrogativas. Sólo posteriormente se convierten en personeros del Estado y defensores de la sociedad.

En el Consejo de Indias existía un Fiscal cuya misión era amparar la jurisdicción y defender el patrimonio y la hacienda reales.

En el Perú Colonial los Fiscales aparecen cuando se instala la Real Audiencia y Cancillería de Indias, en mayo de 1542. Estas instituciones tenían múltiples atribuciones: hacendarias, administrativas, politicas, judiciales, etc. Una de ellas era la judicial, pero no la más importante. Los Fiscales, -que no desempeñaban 'as funciones que hoy ejercen- integraban la Audiencia 
y juntamente con los Oidores desempeñaban las labores que les asignaba las Leyes de Indias. La única diferencia entre ambos consistia en que de modo especial debian velar que los derechos de la Real Hacienda no sufrieran desmedro y que la jurisdicción real fuera respetada.

Con la iniciación de la República aparecen los Fiscales, con atribuciones muy semejantes a las actuales. Desde la Alta Cámara de Justicia hasta la Corte Suprema de la República, cuya instalación en 1825 significó el coronamiento de la organización judicial peruana, siempre encontramos al Ministerio Fiscal al lado de jueces y vocales. Los Reglamentos de 1822 y de 1846 nos lo mencionan como institución. Aparece como tal, pero siempre involucrado con los jueces, en el Reglamento de Tribunales de 1854. En la vigente Ley Orgánica del Poder Judicial, de 1912, constituyen una institución autónoma, con el nombre de Ministerio Fiscal, diferente de la judicatura, con funciones distintas pero laborando a su lado en iguales condiciones de jerarquia y categoria funcional. Cuando Bolivar crea la Corte Suprema de la República, en observancia de lo dispuesto en la Constitución de 1823, debieron ser dos los fiscales, pero disposición transitoria reduce su personal a la mitad - de ocho vocales a cuatro y de dos fiscales a uno-y el primer designado fue el Dr. José Maria Galdiano.

En el siglo XX se perfilan mejor los caracteres de la institución, destacándose como defensores de los intereses de la scciedad en sus diversos aspectos. Hoy, superada la etapa de formación, aparece el Ministerio Público interviniendo en la aplicación de las leyes que sancionan las infracciones penales, asi como vigilando la observancia de aquellas que regulan la capacidad civil y el estado de las personas, las que determinan la competencia de los jueces y la defensa de un derecho del Estado. Tales normas no pueden quedar libradas al arbitrio de los particulares, porque son disposiciones que afectan al orden público. A esta finalidad responde la creación del Ministerio Fiscal que comprende dos ramas: una que actúa ante los Juzgados de Instrucción y Tribunales Correccionales, y otra que solamente interviene ante los Juzgados Civiles.

Por otra parte la representación de los menores e incapaces, en juicio, lo mismo que el cuidado de sus bienes, requiere el control de funcionarios que integran el Ministerio Pupilar. La defensa de los pobres y la representación de los ausentes se halla confiada a quienes constituyen el Ministerio de Defansa. Todas son ramas autónomas de la misma institución, re. gidas por iguales principios. Esta división proviene de las diferentes funciones que desempeñan, pero en su esencia responden al mismo principio de velar por los intereses de la sociedad en sus diversos aspectos. Como entre nosotros no se encuentra establecido el Ministerio Pupilar, su labor se halla confiada al mismo Ministerio Fiscal.

En los paises de derecho escrito, el Ministerio Público está organizado en forma análoga y aunque existen diferencias locales, sus caracteres principales son los mismos. En cambio en los anglo-sajones, en que prevalece el Common Law no existe la institución del Fiscal tal como nosotros la en- 
tendemos. Se encuentra reemplazado por el Attorney, funcionario administrativo que realiza doble labor; perseguir al culpable y reunir las pruebas que acreditan la comisión del de'ito. El Attorney lleva cabo la función persecutoria en nombre del Estado y con la finalidad exclusiva de reunir las pruebas que deberán ser presentadas al Jurado, ante el cual deberá, sostener los fundamentos de la acusación. Aún cuando en dichos países, tanto el Attorney como el Fiscal tienen la misma función acusatoria, sin embargo existe una diferencia capital; este último no es funcionario judicial y por tal razón no integra la Corte; es empleado del Ejecutivo con la función especifica de trabajar para la administración de justicia. Para lograr esta finalidad cuenta con oficina montada con todos los elementos modernos para la lucha contra el crimen: policías, contadores, técnicos, grabadoras, laboratorios, etc., pudiendo secuestrar la correspondencia, intervenir las convérsa. ciones telefónicas para grabarlas, etc.

El estudio de la institución plantea problemas que exigen esclarecimiento previo.

Lo primera que debemos resolver es lo relativo a la utilidad v necesidad de la insiitución del Ministerio Público. Se ha sostenido que realiza una función inútil, carente de sentido y a veces poco simpática: que en mater:a penal exister delitos que pueden quedar ocu'tos con beneficio de la sociedad y sin desmedro de la víctima, lá que nás bien sufre en su buen nombre con la denuncia y persecución pública de estos hechus que ror silencio:a que sea la acción persecutoria de la justicia, siempre trasciende el nombre de la victima y entonces resulta perjudicada doblemente, primero con Ia comisión dei hecho y luego con sia divulgación. Que por otra parte -agregan- son funcionarios que no ejercen jurisdicción, limitándose a dar opinión que carece de trascendencia pará el desarrollo del proceso penal, pues su parecer no obliga al juzgador; que la participación del Fiscal en los procesos orales, no agrega nada a su eficacia, desde que está probado que la acción de los magistrados juzgadores $€$ s suficiente para lograr el compe. to esclarecimiento de los hechos; que en la etapa de la instrucción, tampoco contribuyen $e^{f i c a z n e n t e, ~ e n ~ r a z o ́ n ~ d e ~ q u e ~ l o s ~ i n t e r e s a d o s ~ v i g i l a n ~ s u f i c i e n . ~}$ temente sus derechos, y en e! caso de no hacerlo, el juez es el encargado de perseguir los delitos y reunir las pruebas, pudiendo actuar sin requerimiento de las partes. Por estas razones, muchos autores opinan que el Ministerio Público resulta un "rodaje inútil en la administración de justicia".

Aunque lo expuesto sea cierto, sin embargo las conclusiones a que se llegan resultan falsas y los cargos que se hacen a la institución son infundados. Es evidente que la venganza privada ha quedado desplazada por la sanción del Estado; que el agraviado no puede -y con frecuencia no quiere. o teme hacerlo- perseguir al culpable de la agresión. Si aceptáramos la composición de las partes, muchos delitos quedarian sin sanción, bastando para ello que el culpable tuviera dinero suficiente para pagar lo que la víctima a sus familiares pidiera. De aliî resultaria que la comisión de un hecho 
delictuoso devendria en problema económico, que quien pudiera pagar quedaria exento de pena y quien no, sujeto a proceso penal. Si bien es cierto que el dictamen del Ministerio Fiscal no resuelve nada y que este no ejerce jurisdicción, sin embargo también es verdad que la opinión que emite en cada proceso, es sumanente importante y orienta al juzgador. La présencia de un funcionario diligente y acucioso como representante del Ministerio Público, es de gran ayuda al Instructor y su colaboración resulta eficasisima.

El Ministerio Público se justifica por ser necesario que la sociedad, por si misma, independientemente del Estado y como persona juridica pueda actuar en defensa de sus intereses, cuando se trata de la perturbación del orden público con la comisión de hechos delictuosos o de cuestiones que atañen a la organización misma de la sociedad, cual es la familia.

En materia penal, la organización del Ministerio Fiscal es indispensa. ble porque promueve a la justicia, logrando que los procesos se tramiten en forma debida y oportuna; y persigue el castigo de los culpab'es. Su función acusatoria adquiere mayor trascendencia cuando la victima del delito por temor a la venganza o por razones de pudor, no se atreve a denunciar al delincuente. No son pocos los casos en que la agraviada acusó en forma franca y decidida al autor, mas el transcurso del tiempo, que amortigua las ofensas, y la acción constante de los fami'iares del acusado para que se retracte, determinan que en el acto oral cambie su dicho y dé otro nombre como el de la persona que la perjudicó. Evidentemente, esta variación que hace la agraviada, puede tener consecuencias favorables para el imputado, si no fuera por el representante de la sociedad que debe intervenir para destacar los motives de ese cambio y mantener siempre la acusación contra quien por otros medios ha quedado acreditado ser el autor del delito.

Existen de'itos en los que la sociedad en general, en forma indiscriminada, ha sido ofendida, pero ninguna persona en particular. En este caso no habria interesado en promover la acción penal y esta quedaria únicamente sometida a la dirección que quisiera darle el juez. En otros casos, el agraviado se limita tímidamente a formular su denuncia y luego es despreocupa de sus resultados, quedando el proceso a cargo exclusivo del juez. En estos casos la presencia vigilante del representante de la sociedad es necesaria para el debido control de las actuaciones judiciales de la instrucción.

Es función del Ministerio Público vigilar la aplicación de las leyes de procedimiento que son de orden público. La voluntad de las partes puede resultar insuficiente para obligar al juez actuar en forma debida. La inobservancia de las disposiciones legales que requlan la organización judicial, acarrea la nulidad de lo actuado. Al Ministerio Púbiico corresponde velar po:que tal cosa no ocurra, pues irroga perjuicio a las partes y desr.estigio a la institución judicial.

El segundo problema a dilucidar es el referente a fijar la posición del Miniśerio Fúblico con relación al proceso y a la administración de justicia.

El Prof. Máximo Castro da la siguiente definición: "El Ministerio Público o Ministerio Fiscal es la Magistratura particular encargada de velar 
por el interés del Estado y por el de la sociedad ante los tribunales, promoviendo la represión de los delitos, la defensa judicial de los intereses del Estado y la observancia de las leyes en cuyo cumplimiento está interesada la sociedad" 1 . Esta definición contiene todos los caracteres propios de la institución. Entre nosctros la creación de los Procuradores Generales de la República ha recortado estas atribuciones, pues conforme a la ley, a tales funcionarios corresponde ejercer la representación del Estado en todos los juicios en les cuales sea parte interesada. En provincias, tales funcionarios deberán otorgar poder por escritura pública a un abogado del lugar donde se deba demandar, para que asuma la defensa del Estado.

El Ministerio Público colabora con los jueces en la tarea de administrar jusicia. Debe velar por el cumplimiento de las leyes procesales que son las que reguian el desarrollo del proceso judicial. No tiene actividad instructura ni expide resoluciones. Estas corresponden de manera exclusiva a jueces y tribunales.

Conforme al art. 263 de la L.O.P.J.. el Ministerio Fiscal -asi lo llama nuestra ley- tiene doble participación: como parte y como auxiliar ilustrativo. Es decir, en algunos casos actúa como parte en el proceso, interviniendo activamente en su desarroilo y ejerciendo todos los derechos de las partes de un proceso civil. En otros, deberá limitarse a emitir opinión ilus. trativa para que el juez la tenga presente, quién puede o no seguirla: dice asi la ley "se le oirá antes de pronunciar sentencia, etc. o cuando especialmente lo disponga la ley".

Conforme a este artículo, cuando e! Ministerio Público actúa como parte deberá ser notificado con todas las providencias del juicio, a fin de intervenir en sus incidencias; pero esta intervención queda librada, en cada caso, al criterio de quien lo representa, conforme lo reconoce el art. 584 del C.P.C., sin que pueda exigirsele el ofrecimiento de pruebas ni la peticićn de diligencias determinadas, pues ello atentaría contra su independencia que consagra en forma irrestricta el art. 262 de la citada ley orgánica. Cuando el Minister:o Público se abstiene de intervenir, no es procedente aplicar sanciones, porque entonces el Estado de rebeldia decretado por el juez, le impediría participar en el proceso, ejerciendo el control y vigilancia que le incumbe conforme a la ley. Estos principios vigentes en el procedimiento civil, tienen su adecuada aplicación en el campo penal.

En materia peral, tiene importante participación: es parte en el proceso, representa a la sociedad agraviada por la comisión del delito, con los derechos inherentes a esta situación procesal. Por excepción no pueden intervenir en la instructiva, pero si participa en las demás diligencias y durante la instrucción puede ejercer los derechos derivados de su condición de parte.

Por lo genéral esta participación es obligatoria (arts. 45 y 209). Como excepción a este principio, existen casos en los que la obligatoriedad está supeditada a que previamente la parte agraviada, formule denuncia. 
Cumplido el requisito, el proceso deberá desarrollarse exactamente en la misma forma de los de la participación de oficio. Asi vemos el caso del art. 313 del C.P.P. (delitos contra el honor sexual en agravio de mayores de 16 y menores de 21 ), en que sólo procede abrir instrucción después de la denuncia de la parte agraviada, debidamente ratificada. Diversa situación procesal ofrece la comisión del delito de adulterio, que tambiên requiere denuncia expresa del cónyuge inocente, con la modalidad de qué el desistimiento posterior del agraviado, remite la pena y hace cesar la acción penal instaurada, aun cuando en ella tenga participación el Ministerio Público (Art. 213, del C. P.) También como excepción al principio general de la participación del Ministério Público en todo proceso penal, se encuentran delitos contra el honor, en los cuales no tiene ninguna intervención.

Ser parte tiene una consecuencia de suma importancia: intervenir directamente en el desarrollo de la instrucción, of reciendo pruebas, asistiendo a diligencias, participando en los debates contradictorios, pidiendo la detención de los procesados, oponiéndose a su libertad. etc. Salvo en la instructiva, en todas las demás actuaciones judiciales del proceso penal, deberá intervenir en la forma, dentro de los limites y en las condiciones derivadas el proceso es un documento basado en su participación y la opinión legal que emita tendrá esta sustentación. Dictamen fiscal no es informe legal de un extraño al proceso que emite opinión por el mérito de los autos, sino que es dada por quien habiendo participado en las diligencias de las instrucciones, tiene completo conocimiento del hecho asi como del imputado. Sólo en ta'es condiciones, esta pieza del proceso penal será instrumento de tra. bajo para el juez y para el tribunal.

Pọ su condición de parte y representante de la sociedad agraviada, asi como por el no ejercicio de la jurisdicción, el Ministerio Público no es recusable, pero puede abstenerse cuando se presenta alguna de las causales que justificarian la recusación. La excusa la resuelve el propio Tribuna', no ciendo susceprible la consulta a la Corte Suprema (1927, pg. 510). También deberá excusarse si existieran aqueilos motivos que Manzini denomina "graves razones de conveniencia" y que sólo pueden ser apreciados por el propio interesado. (ver recusación).

Por su condición de parte corresponde al Ministerio Público el ejercicio de la acción penal en defensa de la sociedad agraviada con la coniisión del hecho delictuoso. Tiene la misma situación procesal que el damnificado constituido expresamente en "parte civil", con la diferencia que no acciona por su propio interés sino por defensa de la sociedad.

Dentro de la sistemática del procedimiento penal, el Ministerio Público tiene a su cargo la acusación. Esta palabra imp'ica la pretensión que desarrolla y que sustenta en razones legales. Carnelutti llama "Pretensión Penal Razonada" a la exigencia de castigar a una persona por haber infringido una norma penal; la acusación agrega los motivos legales que fundamentan tal petición. La ley confiere al fiscal la facultad - de la que también participa el juez- de aducir las razones legales que fundamentan una sen- 
tencia condenatoria, procurando evitar fallos injustos o con deficiente sustento legal, y también las abso'uciones por falta de pruebas.

La acusación puede ser pedida por la parte agraviada o lesionada, pero a cargo de ella no puede correr el formularla. La victima o sus familiares pueden ayudar, colaborar, pero nunca reemplaza: al fiscal. Presentaría muy graves peligros el conferir al perjudicado esta facultad; podríamos decir que seria constituido en juez de su propia causa. Por ello, la ácusación tiene carácter público, a cargo del representante oficial de la sociedad. Este principio constituye tradición en el procedimiento penal.

"Acusador es el sujeto que interviene en la relación procesal penal para proponer la pretensión punitiva derivada del delito, a nombre y por cuenta del Estado". Agrega luego Manzini "es el que promueve y epercita la acción penal" 2 .

El acusador público - según esta definición- tiene poder de disposición en el proceso penal y en el ejercicio del mismo, interviene activamente en el desarrollo de la instrucción, como colaborador y hasta cierto punto. controlador de la acción del juez.

Caracteres generales. - La doctrina señala los siguientes: independencia, inamovilidad, unidad; jerarquía.

Los jueces -incluyendo en esta denominación a los propiamente tales $y$ al Ministerio Fiscal - son independientes en el ejercicio de su función. El art. 262 de la L.O.P.J. así lo declara, agregando que deberán desempeñarla segũn su propio criterio "en la forma que estimen más arreglada a la ley. No pueden recibir órdenes de otro poder o autoridad, deberán actuar con absoluta prescindencia de consideraciones extrd-judiciales, teniendo como único objetivo la exacta aplicación de la ley.

Esta independencia no significa que puedan proceder a su arbitrio ni según su leal saber y entender. Su desempeño siempre deberá ajustarse a la ley y a los mandatos del superior jerárquico: "la independencia de los funcionarios del Ministerio Fiscal no es abso'uta: no pueden eximirse de intervenir en la forma, dentro de los limites y en las condiciones derivadas de las ejecutorias pronunciadas por los tribunales" (ejecutoria citada en el libro del Dr. Germán Aparicio y G. S. sobre la L.O.P.J. pg. 161).

Cuando los fiscales "no juzgaren legales las providencias expedidas for el Tribunal, pueden interponer contra eila, los recursos procedentes". (A.). 1912, pg. 310). Tal es el caso del art. 223 que autoriza al segundo fiscal para interponer recurso de nulidad contra el auto del tribunal que le ordena formular acusación; pero el mismo dispositivo éxpresa que si la Corte Suprema declaiara no haber ntlidad en el auto del tribunal que ordena pasar los autos al segundo fiscal para que formule acusación, en realidad está declarando que hay mérito suficiente para pasar a juicio oral y por eso ordena que el segundo fiscal acuse. En virtud de este mandato de la Corte Suprema, el segundo fiscal - contra su propio parecer- deberá formular acusación escrita y mantenerla en el acto oral. Volveremos sobre este punto al comentar el art. 223. 
Debemos aclarar la situación que plantea el inc. $15^{\circ}$ del art. 154 de la Constitución Nacional que establece como atribución del Presidente de la República "Requerir a los tribunales y juzgados para la pronta administración de justicia". Esta intromisión del Poder Ejecutivo, que no se concilia con la independencia de los Poderes, hay que entenderla que se reduce a recomendar la pronta y rápida resolución de los juicios, pero, que no faculta para dar directiva acerca de la forma de tramitar los procesos, ni menos aún sobre el sentido de la resolución final.

Diferente situación se produce cuando e! Agente Fiscal interviene en un proceso en representación del Estadr. Entonces, para el mejor desempeño de su función, recibe las directivas del Ministerio respectivo, puesto que el citado funcionario no tiene porque conocer los motivos en que funda su acción el Estado. Pero debe recordarse que en tales casos, el Ministerio Fiscal actúa como personero del Estado y no como funcionario judicial. La creación de las Procuradurias Generales de la República a cargo de funcionarios estatales, ha cercenado esta atribución que la ley orgánica confiere a los representantes del Ministerio Público. Salvo excepciones -demandas instauradas en provincias donde no hay Procuradores y que las presentan los Agentes Fiscales, provistos del poder suficiente- el Ministerio Público hoy sólo representa a la sociedad agraviada con la comisión del delito y juntamente con el castigo del infractor, deberá perseguir el resarcimiento económico del daño causado con el evento criminal, conforme lo establece el art. 65 del C. P.

La inamovilidad que es nota esencial de la función judicial, comprende también al Ministerio Público: estos funcionarios no pueden ser removidos por acto del Poder Ejecutivo ni trasladados del lugar donde ejercen su función. Si teoricamente el traslado de una ciudad a otra, no constituye agravio, puesto que el cargo es el mismo con igual asignación e idéntica categoria en la carrera judicial, sin embargo, en la realidad, la situación es distinta por la inevitable diferencia que existe en las ciudades del pais, en las diversas zonas de la República y el variable standard de vida. Para la ley, el juez de Lima o Arequipa es exactamente igual al de Jaén o Canta. pero no podemos dejar de aceptar que las condiciones de vida entre unas y otras ciudades son muy difeerntes, y un cambio asi constituiria un evidente perjuicio para quien fuera objeto de la medida. Los cambios o permutas sólo pueden llevarse a cabo a pedido y con acuerdo de ambos funcionarios, siendo necesario, además, aquiescencia de la autoridad judicial. La intervención del Ejecutivo se limita a aceptar el acuerdo de las partes, que tiene el permiso de la autoridad judicial correspondiente, debiendo expedir los títulos respectivos. Constituye nota eséncial en la inamovilidad el que los jueces y el Ministerio Público no pueden ser cambiados del lugar para el cual fueron designados. El funcionario judicial nombrado para determinado cargo sólo puede ser promovido, separado o jubilado, pero nunca ni por ningún concepto cambiado contra su voluntad. 
Tanto los jueces como los agentes tiscales pueden ser objeto de medidas discip'inarias por parte de sus superiores jerárquicos, las que pueden llegar hasta la separación del cargo por la Corte Suprema. La inamovilidad es garantia contra posibles excesos del poder politico pero no constituye una barrera infranqueable que ampare abusos e impida sanciones del mismo poder.

La permanencia en él cargo tiene las naturales limitaciones que establece la ley: separación por juicio o como medida disciplinaria que sólo puede dictar la Corte Suprema; la jubilación voluntaria, o la forzosa al cumplir 70 años; y la no ratificáción por la Corte Suprema en la época en que éstas se llevan a cabo. Fuera de tales situaciones, el representante del Ministerio Público tiene asegurada su permanencia en el cargo; el sentido de sus dictámenes no afectará el éxito de su carrera.

El Ministerio Público es uno. La unidad significa que los diversos agentes que integran la institución deben proceder con criterio uniforme, de tal manera que promovida una acción, los que reemp'ażan en el cargo al funcionario denunciante, están en el deber de continuarlas, aún cuando personalmente fueren de otra opinión. Como el cambio de las personas no altera la institución, el Ministerio Público seguirá la misma linea de conducta trazada por quien intervino promoviendo la acción penal. Esta unidad de criterio es importante porque establece que el cambio de la persona fisica que desempeña el cargo, no altera la opinión oficial de la Institución: iniciada la acción por denuncia del Agente Fiscal, sus continuadores en el cargo, deberán mantener igual criterio que el originario. En e! Tribunal Correccional encontramos la misma unidad: formulada acusación, aunque cambie la persona del fiscal, quien le sucede tiene la obligación legal de mantener la acusación escrita. Es la institución la que permanece, aunque varie la persona - y el criterio- que desempeña el cargo.

La Jerarquia, como último carácter de la institución, consiste en la superposición de grados entre las diversas categorias que integran el Ministerio Público. Asi lo declara el art. 267 de la L.O.P.J.: "El orden jerárquico del Ministerio Fiscal es: Fiscales de la Corte Suprema; Fiscales de las Cortes Superiores; y Agentes Fiscale's". La base de esta jerarquía es la disciplina y dependencia que existe entre sus diversos miembros. La jerarquía no significa separación absoluta entre jueces y agentes fiscales, sino sólo la vinculación derivada de constituir la misma institución judicial.

'En cuanto a su ejercicio, el art. 266 de la citada ley orgánica establece que: "El Ministerio fiscal se ejerce, ante las cortes, por los fiscales, y ante los juzgados de primera instancia, por los agentes fiscales". El fiscal tiene la misma categoria que el vocal y el agente fiscal que el juez. Posteriormente por leyes Nos. 7589 y 7938, se han creado dos Fiscalias en la administrativo "con los requisitos, derechos y obligaciones de los Fiscales de la Corte Sum prema" (art. 10 Ley 7589). Estos funcionarios colocados por ley en la más alta jerarquia judicial, conocen exclusivamente en los asuntos administrativos que corren a cargo de los diversos Ministerios, desarro'lándose su labor cerca de la Administración Pública pero integrando la Corte Suprema de la 
República. Los asuntos estrictamente judiciales -civiles y penales- que llegan a conocimiento del Supremo Tribunal son informados por los otros tres fiscales de dicho tribunal.

En las provincias en las cuales no existen Agentes Fiscales, los Jueces de Primera Instancia nombrarán Promotores Fiscales (art. 272 L.O.P.J.) en las causas que requieran de su intervencićn. El nombramiento deberá recaer "en letrados, si los hay expeditos, y en su defecto, en personas de instrucción y honradez" (art. 272). El Promoto: Fiscal como el sup'ente, transitoriamente integra la administiación de justıcia colaborando con ella. pero sin tener los derechos e impedimentos que la ley establece para los funcionarios de carrera.

Dara Manzini la función principal y caracteristica del Ministerio Público "es hacer valer la pretensión punitiva derivada de un delito"3. Agrega que por su esencia orgánica, por la naturaleza de la función que desempeña y el interés que lo determina, el Ministerio Público como objeto del proceso penal tiene la condición de parte pública en contraposición a las otras (agraviado y tercero civilmente responsable) calificadas de partes privadas en cuanto defienden intereses particulares, que pueden coincidir con los de la sociedad, pero que fundamentalmente son personales. La actuación procesal de una y otras demuestran que estando orientadas por intereses distintos, aspiran a satisfacer exigencias diferentes, aunque no contrapuestas. Sin embargo, estas partes privadas pueden contribuir al desarrollo del proceso penal por intermedio del Ministerio Fiscal haciendo que ejercite las atribuciones que la ley le confiere en beneficio de sus exigencias, con la limitación de que estos pedidos no sean extraños al contenido propio de la investigación judicial.

Por su intermedio pueden pedir pruebas y actuar diligencias que contribuirán al completo esclarecimiento de los hechos.

El Ministerio Público no tiene directo y personal interés en el proceso penal; actúa en nombre de la sociedad que ha sido agraviada con la comisión del delito $y$, en la medida de lo que representa, tiene personeria para denunciar delitos $y$ perseguir su sanción. También deberá tener presente el aspecto económico del evento criminal y deberá perseguir el resarcimiento patrimonial a la victima del delito. Cuando existiere parte civil debidamente constituida desaparece la urgencia de este aspecto por haber quien actúa y demanda el resarcimiento, pero no por allo desaparece la obligación, puesto que siempre el fiscal deberá pedir la indemnización por el daño sufrido. Aunque el agraviado busque la sanción, siempre el Ministerio Público ejercerá su actividad procesal que indudablemente perseguirá el mismo fin. Al mismo tiempo, deberá velár por el cumplimiento de las leyes procesales, función ésta que hace que su participación en el proceso tenga mayor calidad que la de simple acusador.

Cuando el agraviado no desea o no puede apersonarse en la instrucción -vg. por enfermedad, incapacidad, ausencia, etc.- y se desentiende del proceso, entonces la labor del Ministerio Público cobra mayor relieve. 
pues sobre él recae exclusivamente perseguir la sanción punitiva y el resarcimiento económico del delito.

Como función principal, Manzini señala la "Promoción de la Acción Penal" " que consiste en requerir al juez, como uno de los medios admitidos por la ley, para el ejercicio de la actividad jurisdiccional en orden a la pretensión punitiva que se quiere hacer valer. La promoción de la acción penal es una obligación funcional del Ministerio Público: conforme al inc. $2^{\circ}$ del art. 275 de la L.O.P.J. constituye una de sus atribuciones "acusar por los delitos e intervenir en los juicios criminales en los casos y formas prescritas por las leyes".

Ejercitar la acción penal significa "desarrollar ante el juez la actividad necesaria para provocar una decisión definitiva e irrevocable en mérito a esa misma acción o una declaración de no haber lugar a proceder" ". Agrega luego Manzini que "tiene derecho, aunque no tenga absoluto deber, de intervenir en todos los actos procesales". Esta acción la ejercita mediante "requisitorias" que son los requerimientos o conclusiones, según los casós.

Además de la acción persecutoria dei delito, tiene como función proveer que el proceso se desarrolle con la debida regularidad y rapidez, vigilando el cumplimiento de los p'azos legales, la observancia de las normas de la competencia por razón de la materia, del territorio y de la función, calificando debidamente la aptitud procesal del juez, asi como la constitución de la parte civil, la libertad incondicional o bajo caución del procesado, e interviniendo en las demás diligencias que se actúen. Durante el periodo de la instrucción, el Ministerio Público deberá intervenir en todos los actos de la misma, excepto en la instructiva.

En la segunda etapa del proceso penal - la del juicio ora! - tendrá una participación decisiva: sin acusación escrita no puede pasarse al juicio y sin su presencia física no puede llevarse a cabo la audiencia. Cualquier omisión en este sentido, produce nulidad insanables. Posee facultad impugnatoria tanto para apelar de los autos que dicta el juez - vg. libertad, parte civil, embargo- como para interponer recurso de nulidad contra las resoluciones y sentencias que expida el Tribunal Correccional.

Al ocuparnos del juicio oral desarrollaremos con amplitud este punto.

La pretensión punitiva queda satisfecha con la sentencia condenatoria del Tribunal Correccional. Al hacerlo asi el Tribunal ampara la petición del Fiscal, reconociendo la justicia de su fundamento. La sentencia constituye la cesación de toda relación punitiva. La actividad del Ministerio Público iniciada con la instauración del proceso y continuada con el control ejercido durante la instrucción, concluye la sentencia. Alli termina la relación procesal, incluyendo la participación del Ministerio Público. Si bien es cierto que más tarde nace -o puede nacer- la relación derivada de la ejecución de la pena, tanto en lo personal como en lo patrimonial, tales estadios de la relación procesal constituyen lo que con propiedad se ha llamado "cuestiones procesales" que no afectan propiamente al ejercicio de la relación funcional. La ejecución de la pena no constituye el ejercicio de una nueva 
acción, sino es sólo la culminación de la iniciada con anterioridad: la aptitud procesal de las partes queda limitada a la finalidad de la ejecución. Hablando con propiedad, debemos decir que la relación procesal concluye definitivamente con la sentencia del Tribunal, si no se interpusiere ningún recurso impugnatorio o con la ejecutoria suprema en caso contrario.

La sentencia absolutoria tiene las mismas consecuencias procesales que la condenatoria: tambièn pone fin a la pretensión punitiva y la consecución legal es la liberación de todo cargo contra la persona del imputado.

El nombre de la institución ha sufrido diversas variantes debido a la distinta manera como se ha planteado el problema de la acción.

El anterior código -el C. de P. en M. C.- en su titulo II del Libro I lo denomina Ministerio Fiscal "nombre que da una idea restrangida y equivoca de sus atribuciones" dicé la Exposición de Motivos, agregando: "El apelativo de Fiscal recuerda las lejanas orígenes de la institución cuando en Francia el Rey nombraba sus Procuradores para perseguir la cancelación de mu'tas y de los derechos reales". Como hemos visto ejercian sus funciones únicamente en el campo económico. Cuando los derechos del Rey se confunden con los del Estado, sus representantes amplian sus atribuciones y asumen la representación de la Nación. Primero, se limitaban a la persecución de los delincuentes para sancionar las infracciones cometidas por estos; más tarde adquieıen mayor volumen y aumentan sus facultades. Sus funciones se extienden a la defensa de los pobres, de los menores, de los incapaces. Ya no so'ainente perseguirán la sanción de los delincuentes, sino también vigilarán el estricto cumplimiento de la ley procesal y protegerán a aquellas personas que necesitan amparo, por edad, situación económica o estado mental.

Al ampliarse sus atribuciones, la institución adquiere prestancia. Su nombre deberá ser modificado a fin de que comprenda mayor número de funciones. La institución toma una denominación que asi lo expresa: Ministerio Público.

Estará integrada por el Ministerio Fiscal, magistratura especial que labora al lado de los jueces, auxiliándolos en la administración de justicia; el Ministerio de la Defensa, integrado por los defensores de oficio, que tienen a su cargo la defensa de aquellos inculpados que carecen de recursos económicos para sufragar los gastos derivados del proceso penal; y el Ministerio Pupilar que tiene a su cargo el cuidado de las personas de los menores, debiendo velar también por su patrimonio. El C. de P. P. sólo se ocupa de les dos primeros.

Art. 42.- El Ministerio Público está constituido por los Fiscales de la Corte Suprema de la República, los Fiscales de las Cortes Superiores, los Agentes Fiscales y los Promotores Fiscales, que a falta de estos últimos son nombrados por los Jueces Instructores.

Este articulo reconoce la constitución jerárquica del Ministerio Púbìico, que es la misma que la de jueces y vocales: son dos magistraturas que la- 
boran conjuntamente, en un mismo nivel. Reproduce casi en su integridad el art. 267 de la L.O.P.J. que dice: "El orden jerárquico del Ministerio Fiscal es: $1^{\circ}$ Fiscales de la Corte Suprema; $2^{\circ}$ Fiscales de las Cortes Superiores; $3^{\circ}$ Agentes Fiscales". Los Promotores Fiscales no integran la institución y por eso no aparecen en la ley reguladora de la institución judicial. Pero el código procesal los menciona por que constituye una realidad en las provincias donde no existe la Agencia Fiscai; el Juez designa a una persona que llene esta función la que recibe el nombre de Promotor Fiscal, es decir promovedor de la acción del Ministerio Público. Los Promotores Fiscales son nombrados transitoriamente por el propio juez instructor para que intervenga en determinadas instrucciones. El nombramiento por el Juzgado los inviste de las facultades inherentes al Ministerio Público, pudiendo ejercerla sólo en el proceso para el que ha sido designado. Por esta razón, los Promotores Fiscales no pueden denunciar delitos ni ejercer las demás funciones tuitivas en términos generales que la ley orgánica encomienda al Ministerio Fiscal.

Leyes posteriores, expedidas en 1932 y en 1934, crearon las Fiscalias en lo Administrativo con igual rango y categoria oue los Fiscales de la Corte Suprema de la República, aumentando asi su número, pero cuya labor es en el campo administrativo emitiendo dictámenes previos a la expedición de las resoluciones del Poder Ejecutivo. Ejercen función ilustrativa cerca de dicho Poder, pero integran el Poder Judicial.

El C. de P. en M. C. vigente de 1920 a 1940 , autoribaza a los alcaldes, prefectos, sub-prefectos, gobernadores y comisarios de policia, ejercer las funciones fiscales relativas a la denuncia de delitos, debienclo acompañar las pruebas que hubieren recogido. Su labor terminaba cuando iniciada la instrucción. intervenía el Ministerio Fiscal. Ofrecía el peligro de dar intervención judicial en los comienzos del proceso, a personas carentes de preparación y de idoneidad. El actual código no ha conservado esta disposición.

El art. 11 del Código derogado comprendia dentro de esta jerarquia a los "Fiscales Suplentes". Esta disposición ha sido suprimida por innecesaria $e$ inconveniente. Los suplentes son designados por la Corte Superior con duración anual, con el objeto de llenar los vacios producidos por licencias, ausencias, impedimentos, etc. Ejercen las funciones de los titulares solamen. te al ser llamados $y$, por lo general, su intervención se corta en el tiempo y para un sólo proceso o pocas audiencias. Dada su transitoriedad, la vigente ley procesal no los considera como integrantes del Ministerio Público: les falta uno de los elementos propios de la institución, cural es la per. manencia en el cargo.

Conforme a ast. 274 del a L.O.P.J. el nombramiento de los promotores fiscales "recaerá en letrados, si los hay expiditos, y en su defecto, en personas de instrucción y honradez". Por desempeñar función que requiere conocirnientos especiales, el nombramiento deberá recaer en un técnico del Detecho. "Fero si no los hubiere - vg. los abogados han sido o son defensores de las partes- entonces el juez designará a un lego, con instrucción 
suficiente y honradez. Puede presentarse problema si, por eiemplo, el juez estima que el único abogado expedito cárece de preparación u honradez. suficiente para desempeñar bien el cargc, entonces deberá nonubrarlc sienpre o puede recurrir a un lego? Creemo.s que dada la redacción de este ar. tículo, el juez forzosamente deberá désignar Promotor al único abogado, aunque personalmente no lo creyere capacitado. La ley sól: en ei caso de no haber letrados expeditos autoriza designar a quien no es abogado. Esta inflexibilidad tiene su aplicación si consideramos que la opinión a emitir debe estar fundada en el conocimiento de la ley y que, en caso de estar voluntaria o involuntariamente equivocada, ella no obliga al juez.

El nombramiento de los Promotores Fiscales corresponde -..en cada. caso-.. a los jueces para que actúcn en la etapa investigatoria, y a los tribunales para el juicio oral. En ningún caso y por ningún noúvis a la Sala Plena' "El nombramiento de promotor fiscal co:responde al Tribunal Co. rreccional, no a la Sala Plena" (A.J. 1931 pg. 347). Otra ejecutoria suprema establece que "Corresponde al Tribunal Correccional y no at la Sala Plena el nombramiento de Fiscales Suplentes". (A.J. 1943, pg. 513).

Como excepción a las personas que pueden ser designaidas para esios cargos, existen dos ejecutorias: "Los extránjeros no pueden s?: nombrados Promotores Fiscales" (A.J. 1911, pg. 119). Se explica esta prohibición porque el Ministerio Público defiende la jurisdicción nacional y sćlo puede recaer en quienes sean peruanos por nucimiento o por nacionalización. EI extranjero nunca puede sentir estos problemas como el nacional. Aceriás si transitoriamente el Promotor reemplaza al Fiscal, deberá reunir los mismos requisitos de éste y si excepcionalmente puede designarse a un lego en Derecho, en cambio siempre existirá un nacional, tecnico o lego apto para el desempeño del cargo. Es posible que en alguna provincia, no exista abogado expedito, pero siempre habrá alguien nacido en el pais que puedá desempeñar el cargo.

Otra ejecutoria posterior contiene la segunda prohibición: "Los funcionarios judiciales no ratificados, no pueden ser nombrados promotores fiscales" (A.J. 1933, pg. 333). Aunque en forma transitoria, el Promotor Fiscal integra el cuadro de los funcionarios encargados de administrar justicia y. por consiguiente, deberá en lo posible reunir los mismos requisitos de los titulares de la función. Si por mandato constitucional quienes no han sido ratificados están inhabiiltados a perpetuidad para toda función judicial, es consecuencia lógica que no puedan ser nombrados Promotores Fiscales. EI que dejó de ser funcionario judicial en mérito de la no ratificación, tiene inpedimento absoluto de ser designado Promotor Fiscal o Suplente, asi como Juez adhoc, pero no lo tiene para deseinpeñar cargos que aurque colaboran con la administración de justicia, no significan intervenir en la labor de dar justicia a quien la tiene. Por estas consideraciones es que pueden ser desig. nados Defensores de Oficio (A.J. 1938, pg. 6).

El nombramiento del Promotor Fiscal es asunto judicial y no adminis. trativo, a diferencia de lo que ocurre con las suplencias. Los Promotores 
son designados en cada proceso penal y aciúan únicamente en esa instrucción, no en otra. Es decir la designación solamente es válida para la instrucción determinada; no tiene carácter general. En cambio, los suplentes son designados en acuerdo de Sala Plena, por la Corte Superior el 14 de enero de cada año, y deberán jurar el cargo en la ceremonia de apertura del 18 de marzo siguiente. El Suplente es llamado para que se haga cargo de un juzgado o agencia fiscal que se encuentra vacante por ausencia, enfermedad, promoción, etc. y actúa como juez resolviendo o informando en todos los asuntos que radican ante ese juzgado. El promotor es desigrado por el juez o tribunal y actúa en un sólo proceso.

Art. 43.- El Fiscal de la Corte Suprema en lo penal ejerce vigilancia sobre los Fiscales de los Tribunales Correccionales; y éstos sobre los Agentes Fiscales o Promotores Fiscales.

La independencia del Ministerio „Público está condicionada a la vinculación y dependencia derivada de la jerarquia institucional. Conforme a norma constitucional, reproducida por el art. 42 del Código y 257 de la L.O.P.J., el Ministerio Público está estructurado en grados. Integrando el Poder Judicial y siguiendo el mismo principio de la jerarquia institucional, los Agentes Fiscales y Fisca'es de las Cortes Supeciores se encuentran bajo la dependencia y control, de los Fiscales de la Corte Suprema. Esta disposición la consagra, y determina quien es el encargado de ejercerla.

De los tres Fiscales en lo judicial de la Corte Suprema, el menos antiguo tiene a su cargo los asuntos penales y en virtud del dispositivo que comentamos, también le corresponde la vigilancia del Ministerio Público. pero sólo en el ramo penal, puesto que la ley dice: "Fiscales de los Tribunales Correccionales". Es decir que el Fiscal en lo Civil escapa a esta vigilancia, lo mismo que el Agente Fiscal que despacha en el ramo civil ante los jueces de primera instancia. Ahora preguntamos: cuál es la razón por la cual la vigilancia del Ministerio Público sólo funciona en el ramo penal y no en lo civil? Creemos que la razón es sencilla: en esta materia, el Agente Fiscal y el Fiscal emiten opinión ilustrativa, orientadora del juzgador, y cuando son parte, su intervención es reducida.

En cambio en el proceso penal, el Ministerio Público actúa como parte. con intervención más efectiva y participación en todas las ctapas del juicio. teniendo derecho a interponer apelaciones, formular oposiciones y ofrecer pruebes, lo que no ocurre en lo civil, salvo en los juicios de nulidad de matrimonio (art. 583 del C.P.C.) y de divorcio y separación (art. 280 C.C.). En la instrucción, el Agente Fiscal actúa como parte, en representación de la sociedad agraviada y defiende un interés social. En las causas civiles. cuando actúa con este carácter, tiene intervención reducida, nunca igual a la que ocurre con la instrucción; en la miyoria de las causas sólo funciona "como auxi'iar ilustrativo del juez o del tribunal" (art. 263 L.O.P.J.) sin que pueda interponer recursos impugnatorios contra las resoluciones del juzgado. (Ejecutorias citadas por el Dr. Aparicio en su Ley Orgánica pg. 162) 
La vigilancia se manifiesta en observar al funcionario inferior para ver si cumple con su deber, por ejemplo denunciando delitos si los hechos son públicos y notorios, persiguiendo la sanción del culpable y vigilando la observancia de las normas procesales.

Debe entenderse que la vigilancia no debe traducirse en exigencias: v.g. pedrile que dictamine en plazo fijo, que lo haga en sentido determinado, ni que formule denuncias por hechos que el funcionario no considera delitos. El cumplir con la ley no es forzar la conciencia del magistrado: si se cree que un hecho no es delictuoso, ni el superior ni nadie puede obligarlo a que lo denuncie. La independencia que consagra el art. 262 de la L.A.P.J. es inherente a la función y se entiende con respecto al superior jerárquico tanto como al funcionario politico. Según esta disposición de la ley orgánica, el representante del Ministerio Público desempeña su cargo "según su propio criterio" y sobre el criterio no existe vigilancia posible.

El art. 277 de la L.O.P.J. autoriza al Gobierno a instar al Ministerio Fiscal "para que provoque la acción de la justicia en asuntos propios de su instituto, sin perjuicio de lo dispuesto en el art. 262 (que es el que consagra la independencia de los representantes del Ministerio Público). Esta disposición debe entenderse como la autorización concedida al Poder encargado de velar por el orden público para pedir al Agente Fiscal de turno que formule denuncia ante la comisión de un hecho que considere delictuoso, pero no puede obligarlo a hacerlo, si el magistrado cree que no hay delito que perseguir.

El Código contenía un artícu'o -el 14- de mayores alcances que el de la actual ley orgánica. Decia: "El Ministro de Justicia ejerce vigilancia direct a sobre todos los miembros del Ministerio Fiscal para pedirles los datos que juzgue necesarios y requerirlos para el cumplimiento de sus deberes legales". Esta ingerencia era de imprevisibles y muy graves consecuencias: se constituia a un funcionario po'ítico en vigilante del Ministerio Público, estando autorizado para requerirlo y exigirle que cumpliera con sus deberes legaies. Esta disposición era opuesta a la independencia y autonomia del Poder Judicial. Ha sido reemplazada con ventaja por el art. que es materia de este comentario, La vigilancia del propio Poder es recomendable, no as? la que confiere a un poder esencialmente politico como es el Ejecutivo. Asf lo interpreta una ejecutoria: "La independencia de los funcionarios del $\mathrm{Mi}$ nisterio Público no los exime de intervenir en la forma y dentro de los límites derivados de las ejecutorias pronunciadas por los tribunales" (A.). 1922, p. 105). Ampliaremos este comentario en el art. 223.

Art. 44.- El inculpado o el agraviádo, cuando considere que un Fiscal, Agente Fiscal o Promotor Fiscal, no ejerce debidamente las funciones que la ley le encomienda, puede, con independencia del procedimiento que deba iniciarse o se esté siguiendo, ocurrir al inmediato superior quejándose de la acción u omisión que considere indebida. El superior ejercerá las atribuciones que le confiere la Ley Orgánica del Poder Judicial y, en caso necesario, comunicará la queja al Tribunal Correccional para que éste adopte las medidas que juzgue convenientes. 
Como el Ministerio Público ejerce iunciones tutelares que afectan el interés social y también al interés partizular y 10 puede ser recusado, está sometido al control de quienes intervienen en el proceso. La negligenciei - aquella acción u omisión de que habia la ley-es causal de suspensión en el cargo y aún de separación, pero requiere ser probada, es decir, deberá ser puesta de manifiesto por la parte que resulta perjudicada. La queja denunciando la negligencia en que ha incurrido el representante del Ministerio Público, se formula ante el superior jerárquico, que es el Tribunal Correccional con relación al Agente Fiscal y la Corte Suprema cuando se trate de] Fiscal del Tribunal Superior.

Como regla general, las partes del proceso pueden recurrir al superior haciéndole presente las irregularidades sometidas por los funcionarios infe. riores, tanto el juez como el agente fiscal con la diferencia que contra el primero de estos magistrados procede la recusación para separarlo de la instrucción, no asi contra el segundo con quien sólo es procedente la queja que consagra este art. 44.

Tratándose de garantizar la seriedad con que actúan los funcionarios judiciales, para formular queja no es requisito necesario que el agraviado esté constituido en parte civil. Bastará su condición de perjudicado con la omisión del hecho delictuoso para que pueda quejarse del proceder de los jueces. La poca diligencia que muestre el funcionario judicial acarrea perjuicio tanto al agraviado como a la sociedad.

La facultad que confiere este artículo sólo pueden ejercerla el inculpado y el agraviado. El Código derogado en su art. 13 era más amplio; decia así "El acusado, el agraviado o la parte civil, el denunciante, los testigos, peritos y todos los que tengan interés en el juicio criminal..." quedaban facultados para quejarse de la negligencia del Agente Fiscal, Promotor Fiscal o Fiscal de la Corte Superior.

Esta amplitud era excesiva y resultaba inconveniente. Era dar participación en el desarrollo de la instrucción a quienes no podian tener interés permanente en la investigación penal. Pensar que el testigo o perito estabañ interesados en el descubrimientos de los hechos, equivalia a considerarlos parte, perdiendo la objetividad necesaria para actuar como auxiliares. Sólo las partes del proceso penal pueden tener participación en su desarrollo y ejercer el control necesario sobre quienes administran justicia.

El recurso de queja que autoriza esta disposición es tanto más necesaria, cuanto que, conforme a la ley, es el único medio que tienen inculpado y agraviado para controlar la acción del Ministerio Fiscal. No pudiendo ser recusados, las partes se encontrarian inermes ante la negligencia punible de un Agente Fiscal o Fiscal.

Relacionando este art. con el 43, vemos que la queja puede llegar hasta el Fiscal de la Corte Suprema encargado de los asuntos penales quien está autorizado para dictar las medidas necesarias en ejercicio de la potestad de vigilancia que la ley le confiere. Como hemos dicho en el Comentario anterior, el derogado Código en su art. 14 concedia esta facultad de vigilan. 
cia al Ministro de Justicia; lo que era iraceptable desde que un poder del Estado no puede ejercerla sobre los representantes de otro Poder. Era la más absoluta negación del clásico principio de la separación de los poderes. que constituye fundamento y base de niestra organización democrática.

Si bien es cierto que conforme al art. 49, al Juez Instructor corresponde dirigir la instrucción, es indudable que el Agente Fiscal puede y debe colaborar activamente en el desarrollo del proceso. Un funcionario diligente que no se limite a actuar de espectador del proceso, sino que intervenga decididamente en la actuación de pruebas, repreguntando a testigos y peritos. solicitando comparencias y confrontaciones, examinando exhaustivamente al agraviado, etc. contribuye decisivamente a la investigación de los hechos y es inapreciable ayuda del juez. A su vez, la negligencia del Agente Fiscal, la decidia con que actúa, su ausncia en ias diligencias de la instrucción, dificulta la investigación, la que correrá únicamente a cargo del juez. Un Agente Fiscal que observara esta conducta constituye la negación de su misión y hasta puede ser obstáculo grave para el mejor esclarecimiento de los hecho3 sujetos a controversia. Nada decimos de la malicia en el procecier, porque ello entraria en esfera delictiva.

La queja es un recurso que se interpone sin perjuicio del proceso - iniciado o por iniciarse - y es elevada a conocimiento del superior, que más tarde conocerá de la instrucción. Si la queja se declara fundada, el acceder a la petición del quejoso podría significar retirarle la instrucción, la imposición de una sanción disciplinaria o solamente la recomendación de mayor diligencia en la intervención que le corresponda. La primera medida que corrientemente se llama "quitarle la instrucción". constituye una grave sanciön. Aunque su carácter es eminentemente moral sin embargo afecta al funcionario en su dignidad y puede influir en un futuro ascenso. Al Promotor Fiscal sólo puede alcanzarle sanción penal, pues no siendo funcionario de carrera, no puede aplicársele medida disciplinaria.

La redacción de este artículo es defectuosa. Asi por ejemplo, dice que cuando el agraviado o el inculpado considere que el representante del Ministerio Público no ejerce debidamente sus funciones, puede "con independencia del procedimiento que da iniciarse o se esté siguiendo..." formular su queja. iA qué se refiere cuando dice del procedimiento iniciado o por iniciarse? ¿A la propia instrucción donde el funcionario muestra poca. diligencia, o a la que debe abirse con motivo de la negligencia? Es indudable que si la negligencia es tan grave que determina la apertura de un procedimiento penal, es que constituye delito y en ese caso no hay lugar para queja alguna sino sólo para seguir la instrucción. Por eso creemos que este se ha demostrado antes de la apertura de la instrucción: tal es el caso ciel Agente Fiscal que no denuncia oportunamente el hecho, que no se preocupa de ordenar reunir pruebas o las deja perder por acción del tiempo, etc. Ya iniciado el proceso, la negligencia del Ministerio Fiscal es de fácil comprobación y también debe ser sancionada severamente. En conclusión, creemos que la queja debe recaer en la conducta de un funcionario con motivo de 
un evento criminal, bien esté iniciado el procedimiento judicial o aún cuando no lo esté, pero dọl que ya ha conocido o debido conocer el Agente Fiscal.

Oira duda surge de la redacción defectuosa de este articulo. Dice que el "superior ejercerá las atribuciones..." agregando que "en caso necesario comunicará la queja al Tribunal Correccional". Es decir como el superior del Agente Fiscal o del Promotor Fiscal siempre es el Fiscal del Tribu* nal Correccional, debe entenderse que este funcionario es quien debe dirigirse al Tribunal para que aplique las sanciones disciplinarias correspondientes. Pero, si la negligencia proviene del Fiscal, entonces el Superior es el Fiscal de la Corte Suprema en lo pénal. En este caso, preguntamos, ¿también el Fiscal de la Suprema debe dirigirse al Tribunal Correccional para que sancione a su igual? Indudablemente que no. La sanción siempre deberá perseguirla el Fiscal del grado inmediato superior y aplicarla el Tribunal de igual clase, nunca puede conferirse esta potestad a los magistrados del mismo rango y categoria que el negligente.

La interdependencia del Ministerio Público se establecé en los arts. 42, 43 y 44. Si alguno de los representantes de la sociedad dejare de promover determinada instancia, no obstante la denuncia presentada a su despacho o ser púb'ico o notoria la verificación del evento delictuoso, puede el denunciante desatendido o el perjudicado con la omisión, recurrir al superior inmediato formulando la queja que autoriza la disposición que comentamos. Si la queja se declarare fundada, el Tribunal Correccional deberá ordenar la formulación de la denuncia omitida.

iEste mandato del Tribunal Correccional atenta contra la independencia que consagra el art. 262 de la L.O.P.J.? Creemos que no. El criterio del superior jerárquico prevalece contra el del inferior. La independencia que consagra la Ley Orgánica citada es en cuanto al desémpeño del cargo, al criterio que regula la acción de los funcionarios judiciales. Si el superior considera que existe delito en el caso que viene en corsulta, puede y debe ordenarse abra la investigación correspondiente por el mismo juez que denegó la denuncia. Aqui, en virtud del princinio de las instancias jerárquicas, predomina el parecer del Tribunal sobre el juez o Agente Fiscal. La autonomía del juez o del agente fiscal no funciona cuando existe mandato del superior jerárquico, el que debe ser acatado sin formular ninguna observación. Existe una ejecutoria que asi lo declara: "La independencia de los funcionarios del Ministerio Público no lo exime de intervenir en la forma y dentro de los li. mites y en 'as condiciones derivadas de las ejecutorias pronunciadas por los Tribunales" (A.J. 1922, pg. 105).

Es tan grave la obligación de denunciar, que la omisión constituye delito. "El representante del Ministerio Público (que) no interpusiere su acción en los casos en que la ley lo prescribe..." (art. 359 del Código Penal).

Art. $45^{\circ}$ - Son atribuciones y deberes del Ministerio Público:

$1^{\circ}$. Iniciar la acción penal si la corsidera procedente. Pero si la denuncia proviene del agraviado o de sus parientes hasta el cuarto 
grado de consanguinidad o segundo de afinidad, estará obligado a presentarla al juez instructor.

$2^{\circ}$. Denunciar ante el fiscal respective a los jueces instructores que manifiesten parcialidad, descuido o negligencia. Estas denuncias serán apreciadas por el Tribunal Correccional ya sea para regularizar el procedimiento o para reemplazar a los jueces instructores;

3. Vigilar y exigir que se observen todos los plazos establecidos por este Código para la instrucción y el juicio;

49. Dirigirse a todas las autoridades politicas y a la policia judicial, según el caso, solicitando se haga comparecer a las personas cuya concurrencia juzgue indispensable, asi como para que le proporcionen los datos y elementos que considere necesarios;

5. Ejercitar todas las atribuciones y cumplir todos los deberes que le señalan este Código y las leyes vigentes.

Este articulo empieza declarando que el Ministerio Público tiene "atribuciones y deberes". Unas son las facultades inherentes al cargo que se desempeña y otras son las obligaciones de quienes representan al Ministerio Público. Son los derechos y deberes del cargo. Las atribuciones como facultades pueden o no ejercitarse, pero los deberes siempre deben cumplirse. Están tan intimamente vinculadas que pueden considerarse las dos caras de una moneda. El cargo que enviste todo representante de la sociedad invoJucra derechos a ejercer y deberes a cumplir. Por eso esta disposición empieza declarando que tienen atribuciones y derechos que no pueden soslayar.

El primer inciso trata de la acción penal. Se refiere únicamente a la pública, pues en la privada no tienen intervención el Ministerio Fiscal y sólo procede mediante la querella, conforme to declara el art. $2^{\circ}$. Como el articulo dice "iniciar la acción penal" debe enterderse que es instauiada mediante la denuncia correspondiente. Aunque la instrucción comienza formalmente con el auto apertorio, sin embargo debe entenderse que la denuncia lo completa y es en ella conde se inicia la acción penal: denuncia del Agente Fiscal y auto del Juez Instructor constituyen un todo, que marca el comienzo del procedimiento penal.

Por la redacción de este inciso, podria pensarse que en unos casos el Agente Fiscal abre instrucción directamente; y que en otros -cuando hay denuncia previa de la parte agraviada la remite al juez. No hay tal cosa. El único funcionario judicial que mediante el auto apertorio inicia el procedimiento penal, es el Juez Instructor. El Agente Fiscal sólo puede denunciar, no expedir resoluciones, no tiene ninguna facultad de instrucción ni menos de decisión. Como ya hemos dicho, la frase "iniciar la acción penal" debe entenderse como que denuncia $y$ auto apertorio, formando un sólo todo. marcan el comienzo de la instrucción.

Diversos medios tiene el Agente Fiscal para tomar conocimiento de la perpetración de un evento criminal:

$1^{2}$. Directa y personalmente. Si cree que el hecho constituye delito de comisión inmediata, formula denuncia al juez de turno. 
29. El agraviado o sus parientes próximos se presentan a su despacho denunciando el hecho cometido en su agiavio. Deberá recurrir al Juez Instructor haciendo suya de denuncia, en cuyo caso el Juez la considerará con este carácter; o siniplemente la remitirá para que el juez proceda conforme a la ley. Como el Ministerio Público no puede quedarse con una denuncia, en todo caso deberá remitirla al juez que es el único autorizado para abrir instrucción o desestimarla, elevando el auto en consulta al superior.

30. "Cuando en la sustanciación de un proceso civil aparezcan indicios razonables de la comisión de un delito perseguible de oficio el juez dará conocimiento al representante del Ministerio Público para que entable la acción penal correspondiente" (art. $3^{\circ}$ ). En este caso el Agente Fiscal toma conocimiento por la remisión de los autos hecha por el Juez de la causa. Por su mérito el Agente Fiscal formulará la denuncia correspondiente ante el Juez Instructor de Turno. Se trata de hechos calificados de delictivos por la autoridad judicial en el ramo civil.

Pero si el representante del Ministerio Fiscal considera que aquellos indicios no constituyen delito: isiempre debeiá formular la denuncia? Por la redacción de este artículo $3^{n}$ nos inclinamos a pensar que forzosamente el Agente Fiscal deberá formular la denuncia que se lé pide. El Código derogado era más competo, pues decia que en ta'es casos el funcionario oficial "puede expresar al pie de ella que en su opinión no procede la instrucción" (art. 15) párrafo que no ha sido reproducido en la ley vigente.

Pero es al Juez a quien corresponde, en definitiva, el pronunciarse sobre la denuncia. Si encuentra que carece de fundamento, puede declarar que no procede abrir instrucción, bien porque el hecho no constituye delito o porque ha prescrito. El Tribunal Correccional deberá aprobar o desaprobar este auto.

Puede presentarse una situación irregular: el representante del Ministerio Púbico no cumple con remitir la denuncia al Juez, simplemente la retiene, sin darle ningún trámite: iqué camino queda al agraviado? El Código en dos disposiciones da la solución: en el art. 44 -que es objeto de este comentario- se reconoce el derecho de queja ante el superior inmediato, denunciando que el Agente Fiscal no cump'e con sus atribuciones. Por otra parte, el art. 78, expresamente autoriza al denunciante para recurrir al Fiscal -superior jerárquico- para el caso de que el Agente Fiscal no cumpliere con formular la denuncia respectiva; en este último caso la ley dice que el Fiscal "si la encuentra fundada (la denuncia) ordene al inferior para que haga la respectiva denuncia". Es mandato a cumolir. Pero si el mismo Fiscal no encuentra fundada la denuncia, deberá ordenar siempre que el Agente Fisca! la formule? Creemos que no puede ordenar que se formule denuncia si el mismo encuentra que no hay mérito suficiente para ello, pero en tal situación ordenará al funcionario de Primera Instancia que de trámite a la denuncia, puesto que ninguna puede quedarse en su poder, siendo el Juez Instructor el único funcionario autorizado por la ley procesal penal para resolver. 
bien sea abriendo instrucción o declarando que ésta no procede, en cuyo casn deberá éevas la resolución en consulta al superior.

El inciso sogundo consagra la vigilancia que el Ministerio Fiscal debe ejercer sobre el proceder del Juez Instructor. Deberá denunciar cualquier irregularidad que observare, tanto la proveniente de parcialidad con una de las partes como la de punible negligencia. Dificil y desagradable misión ésta. Por ley corresponde al Ministerio Público denunciar a quien tiene igual rango y categoria judicial y que, con frecuencia, es compañero de años en la misma cartera. Frecuentemente esta vigilancia se ejerce por el Fiscal de la Corte Superior ante el Tribunal Correccional, que es a quien corresponde dictar las medidas del caso, tanto las que se relacionen con la marcha del proceso penal, como aquellas disciplinarias destinadas a sancionar al magistrado negligente y evitar repeticiones para el futiro.

Si las irregularidades revisten gravedad, el Tribunal Correccional en ejercicio de la facultad que le concede e! art. 230 , deberá ponerlas en conocimiento de la Corte Suprema, la que en Sala Plena dictará la medida disciplinaria correspondiente, la misma que puede llegar hasta la separación del cargo.

Para enmendar los rumbos equivocados - maliciosos o involuntariosque el Juez ha impreso al proceso penal en su zondición de director de la instrucción, el Tribunal Correccional tiene la facultad de separarlo de su conocimiento, encomendando la causa a otro magistrado de igual categoría. Esta medida constıtuye la sanción adecuada para el caso de la negligencia - ¿́escuido, la vez que regulariza el procedimiento entregando la instrucción a ctro juez para que la tramita dentro de las normas procesales correspondientes.

E1 tercer inciso se refiere a la igilancia que corresponde al Ministerio Público - agentes fiscales y fiscales del tribunal correccional- relativa al cumplimiento de los plazos legales, tanto en la etapa instructora como en la del ;u cio oral. "Plazos son los periodo: de tiempo establecidos por la ley para la realización válida dz los actos procesales". Dentro del ordenamiento procesal penal peruano, existen poccs plazos legales. Sólo por exrepción proceden los judiciales y convencionales y cuando estos se acuerdan no tendrá intervención el Ministerio Fiscal para exigir su cumplimiento.

El plazo de mayor trascendencia para el proceso penal, es el que consagra el art. 202 al estab'ecer como máxima duración de la instrucción, la de se:s meses. Es perentorio y de no cumplirlo, los funcionarios incurren en responsabilidad ante el superior. Dice la ley que a su vencimiento "se elevará indefectiblemente la instrucción al "Tribunal Correccional", pero dentro de esta primera etapa "No hay dia ni hora que no sea hábil para actuar las diligencias de la instrucción", art. 92.

En la segunda etapa del proceso penal, la del juicio, hay más plazos, pero ninguno de ellos tiene el carácter sompulsivo que la ley concede al de la instrucción. En esta segunda etapa existen los plazos siguientes:

8 dias para que el Fiscal emita dictamen. art. 219. 
3 días para que la Parte Civil presente pruebas referentes a la reparación civil. art. 227.

3 días antes de la audiencia para ofrecer nuevos testigos o peritos. art. 232.

entre 8 y 12 días para la nueva audiencia, en caso que el delito revista carácter más grave, previa nueva acusación fiscal, art. 264.

3 dias para suspender la audiencia por enfermedad y que pueda con. tinuar válidamente. art. 268.

24 horas para expedir sentencia, concluidos los debates orales. art. 279.

24 horas para interponer recurso de nulidad. Arts. 289 y 290.

3 dias de recibida la acusación fiscal, para señalar día y hora para la audiencia. art. 229.

El Tribunal Correccional para terminar la instrucción puede acordar ampliaciones que, como es lógico pensar, no pueden exceder del plazo legal, es decir de los seis meses. Aunque el plazo de ley se hubiere vencido con exceso, el Tribunal puede otorgar uno especial, con carácter perentorio, para la práctica de aquellas diligencias que faltan y cuya realización considere indispensable para el juzgamiento. Este plazo judicial deberá ser fijado por el Tribunal; a su vencimiento el Juzgado elevará indefectiblemente la instrucción.

La vigilancia que este inciso éstablece se refiere al estricto cumplimiento de todos los plazos legales, pero de manera especial debemos observar el de los seis meses para dar término a la instrucción; a su vencimiento, el juez, previo dictamen fiscal, deberá elevar indefectiblemente el proceso. Estos funcionarios pueden, si lo creen indispensable, no opinar sobre el fondo del asunto y limitarse a pedir plazo ampliatorio que, según las razones aducidas, deberá ser concedido. Volveremos sobre este punto al comentar los diversos artículos relativos a plazos.

¿La inobservancia de estos plazos, acarrean la nulidad? Debemos distinguir en cada caso. Cuando se trata de plazos perentorios, cuyo vencimiento produce la caducidad del derecho no ejercido oportunamente, su inobservancia determina la nulidad del acto realizado: v.g. una audiencia continuada el quinto dia, es nula; sería improcedente el recurso de nulidad interpuesto pasadas las 24 horas porque el derecho a impugnar la resolución se ha extinguido. En cambio cuando son plazos no perentorios, la inobservancia de los mismos no tiene esta sanción. Tal es el caso de los seis meses: es raro el del proceso penal con inculpado en libertad que se concluya dentro de este plazo, In que si ocurre con los que tienen détenido en cárcel, a los que se les da preferencia. Las diligencias actuadas pasado este término son válidas, situación legal que no puede discutirse por la circunstancia de haberse practicado después de seis meses de iniciada la instrucción.

El cuarto inciso se refiere a la potestad de denunciar. Para formularlas con fundamento el Agente Fiscal puede pedir los datos que juzgue necesarios para apreciar si el hecho constituye delito y no ha precrito. Cuando la denuncia proviene de parte, interesada, el representante del Ministerio Pú- 
blico tiene dos caminos: remitirla al Juzgado tal como la ha recibido; o hacerla suya y con este carácter presentarla. Antes de asumir esta segunda posibilidad, podrá pedir datos ampliatorios al propio denunciante, a la autoridad politica, recabar documentos o alegar cualquier otra prueba que juzgue pertinente. Igual actitud deberá adoptar cuando el hecho sea público y notor:o para, antes de denunciarlo, comprobar la exactitud de lo publicado. El Agente Fiscal no debe olvidar que, por lo general, el presunto agraviado magnifica el hecho y lo que fue simple contusión lo convierte en tentativa de homicidio, de manera que no debe apoyarse en su dicho sino comprobar, hasta cierto punto, la veracidad de lo afirmado.

Pero una vez abierta instrucción, iniciado el proceso penal, esta facultad está condicionada al proceder del Juez Instructor, que es a quien corres. ponde corregirla y actuar las pruebas que estime pertinentes. El Instructor es quien orienta la marcha del proceso penal y el Agente Fiscal puede colaborar con el Juez, pero siempre bajo su dirección; no lo reemplaza ni sustituye ni tampoco puede pedir pruebas por su cuenta. Todo aquello que con. sidere necesario deberá solicitarlo al Juez. Lo contrario seria admitir como posible que existan dos investigaciones, ambas dirigidas por funcionarios judiciales: una, la instrucción, a cargo del Juez y otra, la investigación, a cargo del Agente Fiscal. Esta posibilidad no puede darse porque va contra la unidad del proceso penal, el mismo que la ley procesal entrega exclusivamente al Juez. (art. 49).

Siendo una magistratura independiente del Juez, "Los Fiscales no tienen facultad para dirigir circulares a los jueces sobre las normas que deben seguir" (A.J. 1925, pg. 224). Solamente el Tribunal Correccional puede dictar estas normas a los jueces. Los Fiscales pueden pedir al Tribunal que las dicte, pero no hacerlo por su cuenta. Los Fiscales solamente pueden dirigirse a los Agentes Fiscales y a los Promotores Fiscales. (art. 43).

EJ Agente Fiscal puede solicitar la actuación de pruebas, recabar documentos, comparencias, etc. pero no lo puede hacer directamente, porque ello sería suplantar al juez, y esa no es la intención de la ley.

El inciso quinto comprende todos aquellos casos en los cuales la ley seña'a las atribucionesdel Ministerio Público, así como los deberes a que están obligados. Sería alargar innecesariamente este Comentario si indicáramos los casos en que, por mandato expreso de la ley, interviene el Ministerio Fiscal en el desarrollo de la instrucción.

En cada etapa del juicio -instrucción y juicio oral-_ la ley establece las exigencias que deben cumplirse para que los actos procesales tengan validez.

Teniendo la condición de parte en el proceso penal, la intervención del répresentante del Ministeriọ Público es necesaria. Deberá ser citado a las diligencias de la instrucción, con excepción de la instructiva. En la mayoria de los casos, la comparencia del Agente Fiscal es facultativa (art. 91). En otros, su participación es obligatoria y necesaria para dar validez al acto oral. (art. 234). 
En el curso de estos Comentarios examinaremos las diversas situaciones que pueden presentarse y en cada caso destacaremos el carácter que tiene la participación del Ministerio Público en el acto respectivo.

Art. 46\%,- Los Fiscales intervendrán en las instrucciones por delitos cuyo juzgamiento corresponda a las Cortes Superiores. En este caso el Tribunal nombrará un Vocal Instructor, el cual dependerá de] Tribunal Correccional que se forme. El Fiscal que actúe en una Instruc. ción no puede actuar en la audiencia.

Conforme al art. $80^{\circ}$, inc. $3^{\circ}$ de la L.O.P.J., a las Cortes Superiores co. rresponde "conocer en primera instancia de los juicios por delitos cometidos en el ejercicio de sus funciones, por los prefectos, jueces de primera instancia y agentes fiscales. El art. $14^{\circ}$ de la ley procesal penal reproduce esta disposición.

Cuando las autoridades judiciales y administrativas cometen delitos comunes en el ejercicio de su cargo o con ocasión directa de él, se encuentran sometidas a la justicia ordinaria. Pero no pueden ser juzgados por quienes tienen igual categoria funcional. Necesariamente deberán conocer de estas instrucciones, los funcionarios de supecior jerarquia. La primera instancia estará constituida por las Cortes Superiores y la Segunda por la Corte Suprema. (art. 54, inc. $4^{9}$ L.O.P.J.).

Denunciando el delito el Tribunal Correccional designará un Vocal de los que lo componen, quien con el título de Vocal Insstructor llevará a cabo la etapa investigatoria del proceso. El Fiscal del Tribunal ante quien se ha formulado la denuncia, actuará como Agente Fiscal. Tanto el Vocal Instructor como el Fiscal que actúa como Agente Fiscal, no integrarán el Tribunal Correccional que conocerá del caso. Tienen la causal de recusación que señala el inc. 70 del art. 29.

"Interpuesta denuncia contra un Juez de Primera Instancia, debe el Tribunal Correccional nombrar un Vocal Instructor para que proceda conforme al art. 77 del C.P.P." (R. de los T. 1937, pg. 358 y 1938, pg. 265 y 466). Por tener iguales atribuciones, el Vocal Instructor deberá proceder en la misma forma que el Juez, es decir conforme lo autoriza el art. 77, dictando el auto apertorio, si cree que hay delito, o declarando que no procede la apertura o que el hecho ha prescrito; en estos dos últimos casos deberá elevar lo actuado al Tribunal en vía de consulta.

Con el fin de evitar répeticiones, nos remitimos a lo expuesto en el Comentario al artñ $14^{\circ}$.

Art. $47^{\circ}$. - Si en el Tribunal Correccional que deba conocer en un juicio privativo no hay sino un fiscal, intervendrá en la instrucción un Fiscal suplente.

Conforme al art. 10, los procesos que se siguen contra los funcionarios judiciales por delitos cometidos en el ejercicio de sus funciones o con ocasión directa de las mismas, son privativos porque en su conocimiento no se observará la tramitación ordinaria - juez instructor y tribunal correccionalsino la especial que la ley establece. Se llama privativa porque es peculiar de los funcionarios judiciales y sólo por hechos cometidos en esta condición. 
Las Cortes Superiores de la República varian en su composición, correspondiendo el número de salas al volumen de trabajo. Existen Cortes de cinco Vocales que conforman - alternándose - Sala Civil y Tribunal Correccional; otras de dos salas, una para lo civil y otra para lo penal; y las más tienen varias salas predominando lo civil, en unas, y lo penal, en otras, Cuando existe un solo fiscal en la Corte surge e! problema de quien debe intervenir en el juicio oral y la ley lo resuelve estableciendo que sea un suplente. De esta manera el Fiscal titular actúa en la instrucción, al lado de] Vocal Instructor y el Fiscal Suplente en el acto oral.

La ley ha querido que en la etapa en la cual se reúnen los elementos probatorios que más tarde decidirán acerca de la inocencia o culpabilidad del funcionario enjuiciado, actúe como representante del Ministerio Público quien ejerce como titular. Y para la etapa de la decisión, de la apreciación de lo actuado, en la cual el Ministerio Fiscal sólo tiene labor acusatoria, intervenga el suplente, dejando a funcionarios de carrera - los Vocales del Tribunal - la resolución final del asunto. No pudiendo intervenir en el mismo proceso, primero como Agente Fiscal y luego como Fiscal, es indudable que la ley se ha decidido por la mejor solución, confiando la intervención en la instrucción al funcionario de carrera y la acusación -que no obliga al juzgador- al suplente.

Este artículo se refiere a los Fiscales Suplentes. Aunque en materia legislada en la Ley Orgánica, sin embargo conviene tratarla por la importancia que reviste para la conformación de las salas y la integración del Ministerio Fiscal, siendo válidos los argumentos que se expongan tanto para los jueces como para los agentes fiscales.

En enero de cada año, las Cortes eligen a quienes con el nombre de Suplentes reemplazarán transitoriamente a los funcionarios judiciales. Asumen su cargo el 18 de marzo en que, con motivo de la apertura de los tribunales, prestarán el juramento de ley. Desde ese momento se encuentran capacitados para asumir el despacho de un juzgado a agencia fiscal, cuyo titular transitoriamente no puede atenderlo. Se evita asi la paralización de la función judicial. Mientras que los suplentes se encargan del despacho resolviendo causas y actuando deligencias, los del Ministerio Fiscal se limitarán a recibir los expedientes que les sean enviados, dictaminando y devolviéndolos al juzgado o tribunal.

La ley fija el número de suplentes: tres por cada fiscal y dos por cada relator. Los Superiores elegirán hasta seis vocales suplentes y uno o dos suplentes por cada juez o agente fiscal. (arts. 116 y 117 L.O.P.J.)

Una ejecutoria declara que los abogados extranjeros no pueden ser suplentes (A.J. 1906 pg. 642). En páginas anteriores hemos citado dos resoluciones de la Corte Suprema que establecen que los extranjeros no pueden ser designados Promotores Fiscales y que los magistrados no ratificados tienen la misma prohibición. La razón es la siguiente: con relación a los extranjeros, por su condición de tales no pueden ejercer la jurisdicción nacional; y en lo relativo a los no ratificados, tampoco pueden ser designados suplentes en 
ningún grado, por estar prohibidos constitucionalmente, de integrar la administración de justicia, y en esa condición podrian intervenir en su discernimiento.

La designación de suplentes está comprendida dentro de las atribuciones administrativas de las Cortes de Justicia y las ejercen - salvo excepcionesal finalizar el año judicial. Los elegidos entran en funciones en el año que se inicia el 18 de marzo, previo el juramento de ley que deberán prestarlo el mismo dia de la apertura.

El suplente es un funcionario judicial; tiene potestad jurisdiccional y ha prestado juramento. Solamente falta que la Corte lo llame encargándole el despacho de determinado juzgado. Ocurrido esto, es un verdadero juez con todas sus atribuciones y derechos $y$, en ejercicio de la potestad jurisdiccional de que está investido, puede resolver todos los asuntos que giran ante ese juzgado. El suplente no tiene sueldo, pero le son de abono los años en que preste este servicio. Si la renta estuviere vacante, el suplente tendrá derecho a percibir el haber correspondiente.

A pesar de desempeñar las mismas funciones que los magistrados de carrera, sin embargo la ley le señala dos únicos requisitos: ser peruano de nacimiento y abogado en ejercicio (art. 118 L.P.J.). No menciona el número de años en la protesión de abogado, la edad ni el ejercicio de la ciudadanía, requisitos todos que exige la ley para ei desempeno de vocalías y juzgados (art. 10, 11 y 12). Tampoco menciona el impedimento del parentesco con los magistrados del mismo tribunal. (art. 16 L.U.P.J.) ¿Qué sıgnitıcado podemos darle a la redacción del art. 118? ¿No será necesario que el supıente reúna los mismos requisitos que el titular o interino? ¿Bastará con ser peruano y abogado para ejercer la suplencia?. Creemos que no. Lesempenando las mismas funciones que los funcionarios de carrera, deberán reunir los mismos requisitos. Una ejecutoria suprema así lo ha declarado (El Peruano, 10 de octubre 1944). Lo contrario sería aceptar que un abogado recién recibido pueda ser suplente en Corte Superior e integrar, transitoriamente, el tribunal. Lo mismo puede decirse de los suplentes del Ministerio Público. Tampoco pueden serio en aquellos tribunales en los cuales prestan servicios permanentes sus parientes cercanos. Creemos que los suplentes deben reunir los mismos requisitos que los interinos o titulares, porque, al reemplazarlos, realizan sus mismas funciones. La excepción a este principio general, lo establece la ley al aceptar que los jueces de primera instancia sean reemplazados por los jueces de paz, pero en tales situaciones, sólo están autorizados para determinadas providencias. (art. 121 L.O.P.J.). Es cierto que el art. 116 expre. samente dice: "Los interinos deben tener los mismos requisitos que los propietarios", exigencia que no repite cuando se refiere a los suplentes, pero por la lógica tenemos que no es aceptable que el abogado recién graduado pueda desempeñar la suplencia de una vocalía superior o fiscalía en el Tribunal Supremo. Estas razones explican la ejecutoria Suprema citada. 
Los suplentes reemplazan a los representantes del Ministerio Público - titulares o interinos- cuando éstos se encuentran imposibilitados de cumplir con las funciones tuitivas que la ley les encomienda.

Esta situación puede tener doble causa: $1^{\circ}$ la ausencia v.g. enfermedad, viaje, licencia, etc. $2^{\circ}$. el impedimento v.g. parentesco, haber intervenido en instancia inferior, etc.

En el caso de la ausencia, el Tribunal Correccional llama a los suplentes para que, alternadamente, desempeñen la fiscalía o agencia fiscal. La Corte Suprema ha establecido que en esta situación el despacho debe distribuirse entre varios suplentes, no encargarse a uno solo, pues para eso la ley establece que cada fiscal debe tener tres suplentes. (A.J. 1937, pg. 248).

En el caso de impedimento, la solución es distinta: existiendo dos o más fiscales, el conocimiento de la instrucción pasará al fiscal expedito. Se trata de solo un proceso penal en el cual el titular no puede dictaminar por encontrar que le comprende una causal de recusación y, conforme a la ley. se excusa. Si en la Corte hay un solo fiscal o el otro tuviere también im. pedimento, entonces el Tribunal Correccional recurrirá a un suplente.

La diferencia entre estos dos casos, es muy clara: cuando no existe funcionario nombrado, se encuentra con licencia, ha sido separado o no ratificado, o sea el puesto se encuentra sin titular que lo sirva, entonces el despacho debe distribuirse entre todos los suplentes. Cuando el fiscal desempeña el cargo pero en determinado proceso está impedido, entonces ese expediente deberá ser remitido a conocimiento de otro Fiscal de la Corte, aunque éste sea el que sirve en el ramo civil. Si hubieran varios fiscales en lo penal -como es el caso de Lima, Cuzco, etc.- entonces conocerá de la instrucción el que estuviere de turno, la causa pasará a conocimiento del fiscal de turno más remoto.

No resulta beneficioso para la pronta administración de justicia, disponer que los expedientes que corresponden a la Fiscalia vacante o cuyo titular se encuentra con licencia, sean remitidos a los otros fiscales, pues se recarga su labor perjudicando la atención que debe prestar al propio despacho.

Es más conveniente distribuirlos entre los suplentes, en forma proporcional. Así a cada uno le corresponderá pocas causas.

Art. 48.- Cuando los Jueces de Paz actúan en lugar del Instruc. tor, en los casos señalados en este Código, intervendrá como Promotor Fiscal, necesariamente, el Alcalde Municipal del Distrito o, en su reemplazo, uno de los Síndicos.

En las capitales de provincia residen las autoridades locales y entre ellas se encuentran el Juez de Primera Instancia y el Agente Fiscal. No puede presentarse problema alguno cuando ocurre la realización de algún evento criminal: inmediatamente la autoridad politica avisa al juez, quien se constituye en el lugar de los hechos y dicta las primeras providencias. La presencia e intervención de la autoridad judicial garantiza la autenticidad de la investigación. 
Distinta es la situación en los distritos, caserios y anexos. Las poblaciones pequeñas no cuentan con autoridades judiciales -Juez o Agente Fiscal-, pero en ellas también se cometen delitos que requieren la intervención inmediata del personal del Juzgado. No puede pedirse que el Juez Instructor y el Agente Fiscal, cuya residencia obligada es la capital de la provincia, se constituyan con la prontitud debida, en el lugar de los hechos. La distancia y los malos caminos dificultan y aún impiden esta presencia. Por otra parte, la demora es grave obstáculo que atenta contra la oportuna investigación e impide el recojo de las pruebas del delito.

Para solucionar tales situaciones, la ley autoriza a los jueces de paz - letrados y no letrados- para la práctica de aquellas diligencias que no admitan dilación. (Art. 121 L.O.P.J..

En estos casos la ley procesal no deja en libertad al juez de paz para actuar sólo o con la asesoria de cualquier vecino. Dispone que necesariamente deberá ser auxiliado por el Promotor Fiscal que el fija la ley: el Alcalde o el Síndico Municipal. Esta imposición responde al concepto que en toda instrucción debe intervenir como parte el Ministerio Público y su re. presentante debe ser notificado con todas las resoluciones del juzgado para que participe en aquellas diligencias que considere necesarias.

Cómo se concilia el artículo que comentamos con el 274 de la L.O.P.J. que establece que el nombramiento de promotor recaerá en letrado y si no lo hubiere, en personas de instrucción y honradez? Es indudable que siendo esta disposición propia de los jueces de $\mathrm{Paz}$ que actúan en vez de los Instructores, prevalece la de orden general contenida en la ley orgánica en virtud del principio de que la ley especial rige antes que la general. Además. por lo regular, quienes constituyen los Consejos Muncipales son las personas más caracterizadas del pueblo, y su colaboración con la administración de justicia es beneficiosa.

Este artículo constituye excepción al principio general de que los promotores fiscales son designados libremente por los jueces con quien van a trabajar, a cuyo lado actúan. La ley quiere que ia actividad instructoria de los jueces de paz sea muy restringida, iimitándolas a las diligencias más urgentes, aquellas de impostergable necesidad. También los constriñen impidiéndoles designar a quienes desean, pues obligadamente les imponen como colaborador desde la función del Ministerio Público a quien desempeña la alcaldia o la sindicatura, que puede ser su enemigo político o está distanciado por motivos familiares, sociales, etc. Esta falta de armonía en la labor a desarrollar podría tener graves consecuencias si la función judicial instrue. toria de los jueces de paz no fuera tan reducida; y por ellos carece de importancia tal restricción.

Estando a la redacción de este artículo, es indudable que aunque exista abogado expedito en el distrito, en todo caso el juez de paz debe designar como promotor fiscal a quien lo ordena la ley. 
No declarándolo la ley, se supone que cualquiẹra de los Sindicos - de rentas o de gastos- puede ser designado. Necesariamente el Juez de $\mathrm{Paz}$ llamado a actuar estas diligencias urgentes, nombrará Promotor al Alcalde Municipal y de no aceptar el cargo - v.g. impedimento, enfermedad, etc.a uno de los Sindicos. Si alguna de estas autoridades edilicias no asume el cargo por motivos legales, el Juez de Paz puede designar a otra persona "de instrucción y honradez" como dice la ley? Creemos que sí, pues la ausencia de personas expeditas no puede eximir al Juez de $\mathrm{Paz}$ de buscar a quien colabore con él en la tarea, como representante del Ministerio Público. No pudiendo aplicarse la disposición especial de la ley procesal penal, se recurre a la ley general (ia L.O.P.J.) y se nombra conforme ésta lo autoriza.

1 Curso de Prócedimientos Penales. Buenos Aires, 1928. Tomo I, pg. 295.

2 Derecho Procesal Penal. EJEA. Buenos Aires. 1951. Tomo II. pg. 311.

3 Idem Tomo II. pg. 318.

4 Idem Tomo II. pg. 341.

5 Idem Tomo II, pg. 343. 